\title{
消化器外科之糖尿病
}

\author{
名古屋保健衛生大学消化器外科 \\ 福 井四郎青木春夫
}

\section{PRE-AND POSTOPERATIVE MANAGEMENT OF THE DEABETIC GASTROENTEROLOGICAL SURGICAL PATIENT}

\section{Shiro FUKUI, Haruo AOKI}

Department of surgery School of Medicine Fujitagakuen University

㮂引用語：糖尿病，インスリン持続注入, Branched chain amino acid (BCAA)

\section{I.はじめに}

糖尿病併発患者で高かロリー栄養 (以下 TPN)を施 行した152例について非 TPN 群と対比しつつ, 糖尿病 併発患者の術前, 術後の栄養管理に使用する糖質剤の 質と量, インスリン持続注入法によるコントロールで の術後の糖代謝に対する影響，いかなる組成のアミ， 酸剤が適質かについて述べる。

全重症患者の $95 \%$ \%ンスリンを併用したがインス リンの投与量は, 術前後の尿糖排泄率, 血中之尿中の C-peptid, 経静脈ブドウ糖負荷による $\Delta \mathrm{IRI} / \Delta \mathrm{BS}$ や $\Delta \mathrm{IRG} / \Delta \mathrm{BS}$ などから決定するのが良い(1) 6).

\section{II. 実験対象ならひに方法}

糖尿病患者の程度に応じて, Glucose, Fructose, Xylitol, Maltose, を組み合わせて投与した420名中か ら, Glucose, Fructose, Xylitol, の投与量の比がほぼ 一定となった 5 種類の組み合わせを選んで検討した。

Glucose : Fructose : Xylitol の比 (以下 G:F:X) であるが $6: 4: 1$ の群, 8:4:2の群, $10: 6:$ 1 の群, $10: 6: 2$ の群の組み合わせが多いので, こ れらの群のなかで中等症と重症を対象として検討し た.

つぎに糖尿病併発患者の術前, 術後管理にTPNを 抗こなった症例152例中，インスリンの持続注入法に よってコントロールを施行した重症中等症の症例19例 について,インスリン持続注入法に打ける尿糖排泄と の関連性について述べる。

インスリンを持続注入した 23 例中，軽症 4 例，中等

※第26回日消外総会シンポ I：消化器外科と糖尿病 $<1985$ 年11月12日受理 >別刷請求先 : 福井 四郎

干448 刈谷市井ヶ谷町広沢 1 愛知教育大学
症 8 例, 重症11例である.

また糖氺症併発患者で TPN 群(123例), 非 TPN 群 (145例), さらにインスリン持続注入群 (23例), 非持 続注入群のなかから, 術前術後のアミノ酸代謝並びに 尿糖との関連性について検討した. また, 本論文では, 血糖値，尿糖排泄，血中，尿中の Glucose 值，Xylitol 值, Fructose 値, アミノ酸分画についての測定値を中 心とした。

\section{III. 成 績}

(1) 糖質について

Glucose の排泄量について（図 1)

(1) 中等症群はぞの群も, 術後 $3 \sim 4$ 日目に多く, そ の後, 経日的に减少する。しかし,この 3,4 日目に投 与総糖の7.5\%を越える症例は少ない. 経日的に減少す る度合であるが, $10 ： 6: 2$ 群, $8: 4: 1$ 群, 8 ： $4: 2$ 群の順に回復が早い.

(9) 重症群は, 術後 6:4:1 群が他の 2 群より術 後いずれの日でも排泄の度合が小さく経過している. 又, $8: 4: 1$ 群は, 術後 1 日目に, $10: 6: 1$ 群は, 術後 3,4 日目にむかって増量し, その後, 経日的に減 少する.しかし，6：4：1群の回復率には及ばない。

Fructose の排泄量について（図 1)

中等症, 重症群ともに術前, 術後 $5 \%$ 内外の排泄で ある.

(1) 中等症群はどの群も術後 1 日目の排泄が一番多 い. その後, $8: 4: 2$ 群は, 術後早期に術前値に回 復しているが, $10 ： 6 ： 2$ 群は, ゆるやかに回復し, 8：4：1群は, 7 日目でも術前値に回復していない. しかし，どの群も5\%を越えていない。

(1) 重症群は, 10:6:1群が術直後から7日目まで 
図 1 糖尿病の術後に打ける投与する糖の組成々尿糖 排泄との関連性（尿糖は糖の投与量に対する100分 率)

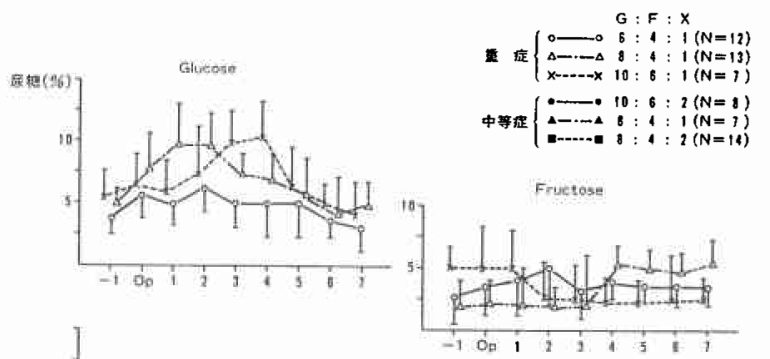

図 2 糖尿病の術後における投与する糖の組成と尿糖 排㳜との関連性（尿糖は糖の投与量に対する 100 分 率)
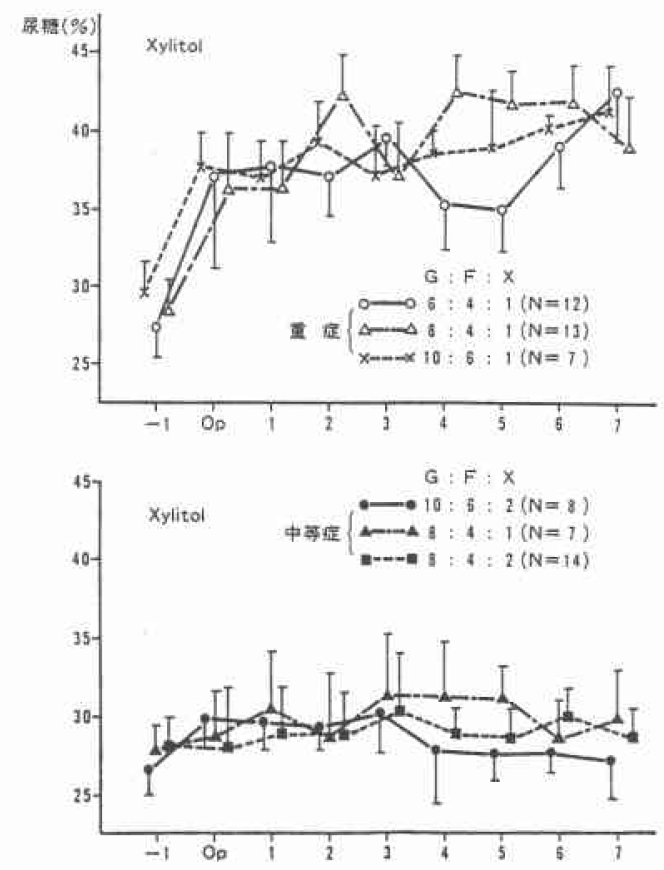

減少し続け，7日目では術前値の約半分近くまで減少 している. $8 ： 4 ： 1$ 群は, 術後 3 日目迄術前値と同 じ量だけ排泄し，4 日目から経日的に増量する，6： 4: 1 群は, 術直後からやや上昇して 2 日目にピーク に達し，その後減少する。しかしどの群も，5\%を越 光ない.
Xylitol の尿中排泄量（図 2 ）

(1) 中等症群は, どの群も術前, 術後 7 日間を通して, $25 \%$ 30\%の排泄である. 術後 3 日目迄， 3 群ともに 類似した傾向を示して上昇する。しかし, その後経日 的に 3 群の推移は，若干ことなるが， 3 群とすに 7 日 目で術前値近くに回復している，しかし，10：6：2 群の回復が 1 番早い.

(2) 重应群, 術前25３0\%の排泄が術日どの群も40\% 近く迄上昇し，その後，経日的に同じうな量だけ排 泄する。しかし，4日目からは，6：4：1群は減少 し, 8：4：1群は, 上昇し, $10: 6: 1$ 群は変動が ない.また, どの群も術後 7 日目には術前値には回復 していない.

以上のよらに，糖質剂のそれぞれの組み合わせに よって, 術後の尿糖排泄に特徵が認められるが, 一般 的に術後 1 日目は，排泄量が多く，その後経日的に減 少する傾向にある。しかし，その組合わせによって， 多いに差がある.

（2）インスリンの持続注入法によるコントロールと 糖代謝

一日糖投与総量とインスリン投与量の比, (以下投与 G/I 比）を持続注入法の前と持続注入により安定した 後（術直前）とで比較した（図 3,4）.

重症群は, 持続注入後, 投与 $\mathrm{G} / \mathrm{I}$ 比は, 11例中 9 例 が高くなっている，すなわち，持続注入前 G/I 比の平 均 9.5 が, 持続注入後平均 12 之高くなっている. 持続注 入後減少している 2 例は, 注入前平均 $8.2 て ゙$ 持続注入 後, 安定した時には，平均5.5であり，この 2 例はとも に術日に糖の投与量をる減少せしめざるを得なかった 症例である(図3).

中等症群では，持続注入後投与 G/I が高くなってい

図 3 TPN (馴化良好群)，Insulin 持続注入糖尿病併 発患者の尿糖排泄量と投与総糖/投与総 Insulin の 関係 (重症群)

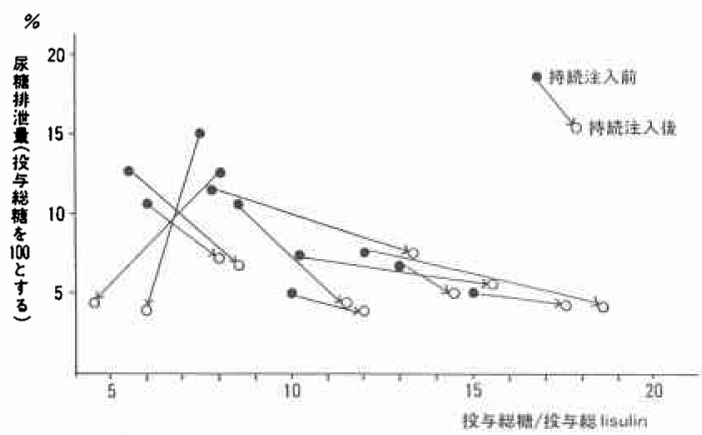


図 4 TPN (馴化良好群)，Insulin 持続注入糖尿病併 発患者の尿糖排泄量と投与総糖/投与総 Insulin の 関係 (中等症群)

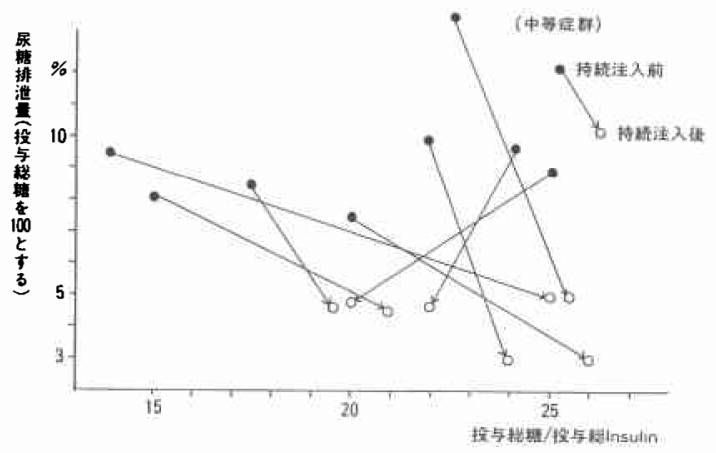

る症例は 8 例中 6 例である.すなわち, 持続注入前 17.5 から持続注入により安定した時期の, 投与 G/I 比は, 22 と高くなっている. 持続注入後減少した 2 例である が，持続注入前投与 $\mathrm{G} / \mathrm{I}$ 比平均 24 から注入後投与 $\mathrm{G} / \mathrm{I}$ 比平均21に，やや減少している.しかし，この 2 例は, 術日, 衍後 1 日目とともにインスリン量も糖も術直前 と同じ量で管理せしめえた症例である（図4）.

インスリン持続注入による投与 $\mathrm{G} / \mathrm{I}$ 比と尿糖排泄 の関連性について述べる.

重症群であるが，11例中 9 例が持続注入後投与 G/I 比が高くなった，しかしこの 9 例は，尿糖排泄が減少 し安定した。11例中 2 例は尿糖排泄を安定せしめるた めに投与 $\mathrm{G} / \mathrm{I}$ 比を低くせざるをえなかった症例であ る.

中等症群であるが，この群は注入前いずれの患者す コントロールがやや困難でインスリンと尿糖排泄の関 連性が乱れていた症例である。しかし，この群で持続 注入により尿糖排泄が安定し, 投与 G/I 比を高くせし め克た。

しかし，投与 G/I 比を低くしなければ尿糖排泄が安 定しなかった症例が 2 例である。しかしこの 2 例は， 術日術後 1 日目のインスリン量, 糖の投与量の増减は なかった。

つぎに術前 TPN とともにインスリンの持続注入に よってコントロールが十分に行われた時に, 手術侵菨 が加わった時の術後の尿糖排泄について述べる（表 1 ).

中等症群でのインスリン非持続注入群であるが, 術 日，術後 3 日目迄尿糖排泄が糖投与総量の $10 \%$ 以上の 症例は, 全症例の70〜80\%認められる.これに対して,
表 1 手術侵襲時に拈ける TPN (馿化良好群)・Insulin 持続注入糖尿病併発患者の尿糖排泄量（\%)

\begin{tabular}{|c|c|c|c|c|c|c|c|c|c|c|}
\hline & & 術前 & 街日 & 1 & 2 & 3 & 4 & 5 & 6 & 7 \\
\hline \multicolumn{2}{|r|}{$\%$} & $<10<$ & $<10<$ & $<10<$ & $<10<$ & $<10<$ & $<10<$ & $<10<$ & $<10<$ & $<10<$ \\
\hline \multirow{2}{*}{$\begin{array}{l}\text { 非 } \\
\text { 躃 } \\
\text { 注 }\end{array}$} & $\begin{array}{c}\text { 中等症 } \\
n=11\end{array}$ & $11: 0$ & $4: 7$ & $4 \div 7$ & $5: 6$ & $3: 8$ & 38 & $5: 6$ & $4: 7$ & $2: 9$ \\
\hline & $\begin{array}{c}\mathbf{E} \\
n=9\end{array}$ & $9: 0$ & 3: 6 & 3: 6 & $2: 7$ & $2: 7$ & $1: 8$ & $2: 7$ & 45 & $3: 6$ \\
\hline \multirow{2}{*}{ 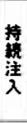 } & $\begin{array}{r}\text { 中等症 } \\
n=8\end{array}$ & $8: 0$ & $8: 0$ & $8: B$ & 8,0 & 0 & $7: 1$ & $7: 1$ & $8: 0$ & $8: 0$ \\
\hline & $\begin{array}{l}\mathbf{1} \\
n=11\end{array}$ & 9 & $9: 2$ & \begin{tabular}{l|l|l|} 
& 1 \\
& 1 \\
\end{tabular} & $8: 3$ & $7: 4$ & $7: 4$ & \begin{tabular}{l|l}
8 & 3
\end{tabular} & $9: 2$ & $9: 2$ \\
\hline
\end{tabular}

持続注入群ではほとんどの症例が術日, 術後のいずれ です尿糖排泄が10\%以内に怙さえられている。

重症群での術日, 術後 1 日目の尿糖排泄量であるが, インスリン非持続注入群では，糖投与総量の $10 \%$ 以上 排泄が，全症例の70 75\%であるのに対して，持続注 入群では, 10\%以上の排泄が全症例の30 40\%である。 また, 術後 $3 \sim 4$ 日目では, 非持続注入群で $10 \%$ 以上 の排泄が全症例の 80 ９0\%であるのに，持続注入群で は全症例の 25 30\%である，すなわち，術前，インス リン持続注入によるコントロールは, 術直前または術 後の経日的な糖代謝の乱れが小さく，尿糖排泄が小さ く，管理が容易である.

（3）アミノ酸放について

血清中のアミノ酸と尿糖排泄との関連性について, 種々の検討を加光た。

術前, 術日, 術後 3 日目のいずれの日でる TPN 群, 非 TPN 群, ともに Leu/ILeu と, 尿中糖排泄量との間 に，比例的関係がある，すなわち，術前では，尿糖排 泄を $5 \%$ に保つには, Leu/ILeu 比は， 2 前後が，術日 は1.8前後が術後 3 日目は 1.4 前後が望ましく, 正常人 の術後のそれと異なることを示している（図5）.

手術侵襲によって, 血清中の遊離 $ミ$ ノ酸の経日変 動であるが，異化期減少する Typeのアミノ酸と上 昇する Type のアミノ酸がある。

糖尿病患者の術後では, 减少する Typeのアミノ酸 は, Ala, Glnなどの glucogenic amino acid であり上 昇する Type のアミノ酸は, BCAA 等のアミノ酸であ り，これらのアミノ酸は糖尿病の重症度が強くなるに つれて，この異化期での増加する度合が強くなる。

このように手術侵襲自体が，アミノ酸代謝に対する 影響る大きく，さらに併用する糖質剤との関連の上に たって術後, 個々のアミノ酸はそれぞれの特徴ある推 
図 5 糖尿病併発患者に㧍ける手術侵站による leu/l. leu と尿中糖排泄率との関連性

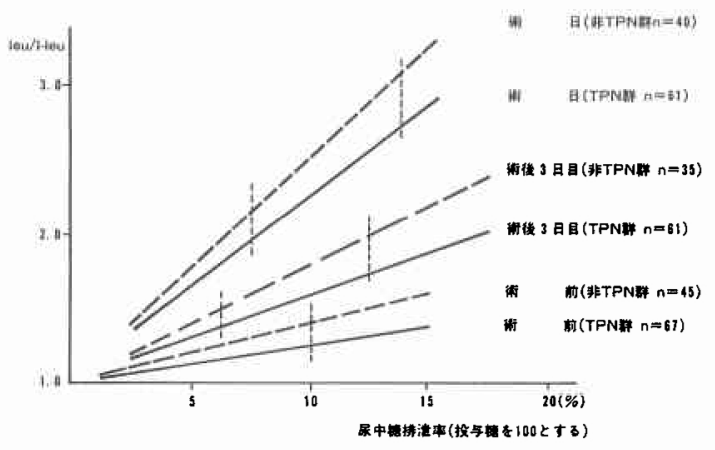

表 2 ヒトの糖尿病併発患者胃切 3 日後の Branched chain aminoacid の相関

\begin{tabular}{|c|c|c|c|c|c|}
\hline & & & Heu & Lev & Val \\
\hline \multirow{3}{*}{ 軽 } & 粡前侹 & $n=9$ & $74.2 \mu \mathrm{mol} / \mathrm{s}$ & 121.8 & 230.5 \\
\hline & 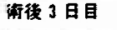 & $n=9$ & 89. $0 \mathrm{H}$ & 170.5 & 253. 6 \\
\hline & $\begin{array}{l}\text { 街前健 } \\
1 \text { とす }\end{array}$ & & 1.2 & 1.4 & 1. 1 \\
\hline 症 & $\begin{array}{l}\text { Heuを } \\
1 と す る\end{array}$ & & I & 1.9 & 2.8 \\
\hline \multirow{4}{*}{$\begin{array}{l}\text { 中 } \\
\text { 等 } \\
\text { 症 }\end{array}$} & 葕前值 & $n=7$ & 105. $7 \mu \mathrm{mol} / 1$ & 170.3 & 241.3 \\
\hline & 爾後 3 日目 & $n=1$ & 148. $8 "$ & 289.5 & 313.1 \\
\hline & 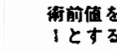 & & 1.4 & 1.7 & 1.3 \\
\hline & $\begin{array}{l}\text { 1-ieuを } \\
\text { くとず }\end{array}$ & & $i$ & 1.95 & 21 \\
\hline \multirow{3}{*}{ 重 } & 街前任 & $n=5$ & $135.4 \mu \mathrm{mol} / \mathrm{I}$ & 201.5 & 286.7 \\
\hline & 術啳 3日目 & $n=5$ & 162.51 & 390.0 & 302.5 \\
\hline & $\begin{array}{l}\text { 得前殸 } \\
\qquad と す\end{array}$ & & 1.2 & 1.9 & 1.1 \\
\hline 应 & $\begin{array}{l}\text { 1-ieu\& } \\
1 と す す\end{array}$ & & 1 & 2.4 & 1.8 \\
\hline
\end{tabular}

移を示す。

このように糖疗病患者の術後では BCAA のフミ 酸は異化期に増量する Typeのアミノ酸であり, 重症 になるにつれて，この度合は大きくなる. I-leu., Leu, $\mathrm{Val}$ ，とか BCAA の総量とか，I-Leuを 1 とした時の Leu., Val, の比などは，術後 3 日目，7日目は，それ ぞれ，正常人のそれと比べて大きく乱れている。特に， 3 日目は, どの数値す, 中等症, 重症となるにつれて 増加し，かっこの比は大きく乱れている(表 2 ). 特に, 術前値を 1 とすると， 3 日目に乱れる傾向は，Leuに 強くあらわれる。しかし, 重症糖尿病患者で術前のイ ンスリン持続注入群では，この傾向はやや弱まる。 た, I-Leu を 1 とした時の術後の変動であるが, この比 は異化期に, Leu/I-Leu は重症群で高く, Val/I-Leu は
低いが術前のインスリン持続注入群では，この傾向が やや弱まり正常値に近づく.さらにこれらの関連性は, 糖質の種類と使用されるアミノ酸剤の組成によって大 きく左右される。

\section{IV. 考察}

以上のことから glucose の排泄量からでは，中等症 群は10：6：2 の比の群が, 重症群は $6: 4 ： 1$ の比 の群が望ましく, Fructose の排泄量からでは $8 ： 4 ：$ 2 の比の群が, 重症群は10：6：1の比の群が望まし く,Xylitol の排泄量からでは，中等度は10：6：2の 比の群が, 重症群は, 6:4：1の比の群が望ましい ことがわかった。したがって糖尿病ですそれぞれの病 態像に適応した糖質のそれぞれの比で投与すべきであ る.

糖尿病患者の重症度がすすむにつれて Acetyl-CoA から脂肪酸に再合成される時に役をなす補酵素 TPNH (環元型 triphospho-pyridinenucleotide) が増 加する.TPNH はその関連系の五炭糖リン酸回路の代 謝は糖尿病患者では円滑でなく,TPNH 産生は減少し ているので, 脂肪酸の再合成が減少し, Acetyl-CoA の 過鄱状態からケトン体生成へとすすむ率が多くなる。

したがって重症糖尿病の場合にはXylitol の占める 量を特に考虑すべきである。

また，糖尿病併発患者の術前, 術後には, TPNを十 分に馿化させるととるに，インスリンのコントロール には，持続注入法によって，術前から十分に馿化させ ることが, 術日と術後の糖代謝, 蛋白代謝の乱れを减 少させ，かつその他の管理をも円滑にさせる。

糖尿病患者の蛋白代謝であるが.

(1) 糖尿病群では, glycolytic-Keyenzyme 活性は低 下し, gluconeogenetic Keyenzyme 活性の上昇が認め られる。

(2) アルブミンの肝での合成は，低下している。すな わちインスリンは，蛋白合成に㗢くので肝での蛋白合 成は低下している。

このような糖尿病患者には，いかなる組成のアミ， 酸哓が良いのか，特に branched chain amino acid(以 下 BCAA）について臨床例を中心に検討したが，糖尿 病患者の血清遊離アミノ酸は。

(1) 重症になるにつれて,多くのアミノ酸は上昇する 傾向にある．特に，BCAA にその傾向が強い。

(2) しかし軽症, 中等症群では, Ala., Gly., Thr., Ser., は, 逆に減少する。

(3)インスリン投与によって, BCAAとか, 
Ketogenic amino acidは減少し，正常化に向から。 臨床例でも，STZ-Wister ratsでも，血糖値とか血 清中のインスリン值と大きく関連性が認められるアミ ノ酸は, Leu., Arg., Ala., などである.

一方，われわれは個々のアミノ酸のなかでSTZWistar rats で, $\beta$ 細胞に対しその病態像に関連を持ち つつ，賦活作用のあることをみいたした。すなわち， Leu., Arg, Ala., がほかのフミ/酸よりもその力は大 きい.しかし， $\alpha$ 細胞に対しても影響力があることは， いなめない。

以上のことから, Leu., Arg., Ala., は糖尿病の病態 像によって変動を示す。したがって, 糖尿病のアミ， 酸剤の組成は，糖尿病の悪化度によって考㦄せ就ばな らない。すなわち，BCAA に限って言及するならば， 軽症時に括けるアミノ酸剤は, Leu., Arg., Ala., らの アミノ酸の占める量を多くし，重症糖尿病になるにつ れてこの比を考慮すべきである。手術侵熟時における 異化期に, 糖, 脂肪 etc のエネルギー源の投与が生体に とって不足であるならば, BCAA の血中における増加 率は高い. 血糖値の上昇に比例して, Leu-Ala-glucose cycleが亢進するといわれているが，特に，この LeuAla-Pyr-glucose cycle に括ける酵素活性が，手術侵楽 においてす賦活され六進しているので, BCAA とくに Leu の占める役割は大きい. 又, Leuが $\beta$ 細胞を賦活
する力が泳のアミノ酸よりも大きいので糖尿病，な かんずく術後に利用される意義も大さい。

おわりに

糖尿病術前術後管理には, 高カロリ一栄養法が良い。 その際,

1. 糖質斉の組み合わせによって, 尿糖排泄に特徽が あるので重症になるにしたがって，組み合わせを考慮 すべきである。

2.インスリンの持続注入法のコントロールは術後 の糖代謝の乱れが小さい，

3. 術前・術後のアミノ酸剤は重症に移行するに従っ て，BCAAのしめる割合を考慮すべきである。

\section{文 献}

1）福井四郎：特殊状熊，とくに糖尿病併発患者の術 前・術後管理。日外会誌 $76: 85-88,1975$

2）福井四郎：Hyperalimentation に打汸糖質の適 量について. Med Postgrad 13:32-56, 1975

3）福井四郎：糖尿病患者における高カロリ一輸液。 手術 $32 ： 669-678,1978$

4）福井四郎：糖尿病患者の術前・術後管理としての Hyperalimentation。日臨 37:97-104，1979

5）福井四郎：榶尿病合併例の術前・術後の栄湌管理. 手術 35：1439-1447，1981

6）市原 明：分岐鎖了ミ>酸の生化学. 輸液・栄 シャーナル 3：101-108, 1981 